\title{
Z problematyki prawnokarnej oceny zbiegnięcia sprawcy z miejsca przestępstwa drogowego
}

\author{
RAJNHARDT KOKOT \\ ORCID: 0000-0002-6240-7282 \\ Katedra Prawa Karnego Materialnego \\ Wydział Prawa, Administracji i Ekonomii Uniwersytetu Wrocławskiego
}

Problematyka prawnokarnego wartościowania ucieczki sprawcy z miejsca zdarzenia w komunikacji na płaszczyźnie normatywnej, ale i kryminologicznej należy niewątpliwie do bardziej spornych zagadnień prawa karnego. Jej złożony, wielowarstwowy, a przez to i kontrowersyjny charakter ujawnia się na gruncie zarówno dogmatyki prawa karnego, jak i orzecznictwa sądowego. Problem zasadności ustawowej regulacji tej okoliczności, jej funkcji, zakresu czy kwalifikacji zachowań sprawcy, który zbiegł z miejsca zdarzenia - nierzadko także w kontekście nieudzielenia pomocy ofierze zdarzenia, które spowodował — był w ostatnich dekadach wielokrotnie przedmiotem analizy w polskiej literaturze prawniczej ${ }^{1}$. Zmianie

${ }^{1}$ Zob. np. T. Cyprian, Ucieczka kierowcy, „Palestra” 1962, nr 1-2; W. Radecki, Odpowiedzialność karna kierowcy za nieudzielenie pomocy ofierze wypadku, „Problemy Praworządności" 1975, nr 10; K. Buchała, Przestępne zaniechanie udzielenia pomocy w niebezpieczeństwie grożącym życiu człowieka, „Państwo i Prawo” (dalej: PiP) 1960, nr 12; A. Zoll, Odpowiedzialność karna kierowcy za spowodowanie wypadku i nieudzielenie pomocy jego ofierze, „Wojskowy Przegląd Prawniczy” (dalej: WPP) 1969, nr 1; idem, Odpowiedzialność karna kierowcy za ucieczkę, „Nowe Prawo” 1970, nr 10; idem, Kilka uwag w zwiazku z charakterem prawnym norm sankcjonujacych wynikających z art. 178 \& 1 k.k., [w:] Teoretyczne i praktyczne problemy wspótczesnego prawa karnego. Księga Jubileuszowa dedykowana 
ulegała jedynie dynamika zainteresowania tą kwestią, które zauważalnie zwiększało się wraz z kolejnymi zwłaszcza „przełomowymi” w tym zakresie rozstrzygnięciami judykatury ${ }^{2}$ bądź zmianami w normatywnym ujęciu tej okoliczności w ustawie karnej ${ }^{3}$. W ocenie charakteru prawnego ucieczki sprawcy z miejsca zdarzenia trudno mówić o wypracowaniu stabilnego konsensusu. Opinie na ten temat są niezmiennie podzielone, choć ich polaryzacja nie jest już tak znaczna, jak pod rządami poprzednio obowiązujących kodyfikacji karnych. Na gruncie obowiązujących rozwiązań prawnych zbiegnięcie sprawcy w ujęciu art. $178 \S 1$ k.k. przez większość przedstawicieli doktryny prawa karnego, a także przez orzecznictwo sądowe traktowane jest jako zachowanie kształtujące wymiar kary, stanowiące jedną z podstaw jej nadzwyczajnego obostrzenia ${ }^{4}$. W obowiązującym sta-

Profesorowi Tadeuszowi Bojarskiemu, red. A. Michalska-Warias, I. Nowikowski, J. Piórkowska-Flieger, Lublin 2011; idem, Glosa do uchwaty SN z 16 marca 1999 r., I KZP 4/99, „Orzecznictwo Sądów Polskich” (dalej: OSP) 1999, nr 11; K.J. Pawelec, Ucieczka sprawcy wypadku drogowego w świetle prawa karnego i badań, „Służba MO” 1986, nr 3-4; L.K. Paprzycki, Ucieczka z miejsca wypadku drogowego, „Rzeczpospolita” 1995, nr 118; K. Buchała, Problemy kryminalizacji ucieczki uczestnika karalnego zdarzenia w ruchu drogowym, „Prokuratura i Prawo” (dalej: Prok. i Pr.) 1995, nr 2; R.A. Stefański, Ucieczka sprawcy z miejsca wypadku drogowego, Prok. i Pr. 1996, nr 1; M. Dąbrowska-Kardas, P. Kardas, Kryminalizacja ucieczki sprawcy wypadku drogowego z miejsca zdarzenia w świetle nowelizacji k.k. z 12 lipca 1995 r., cz. 1 oraz cz. 2, „Palestra” 1996, nr 3-4 oraz nr 5-6; J. Iwaniec, Glosa do uchwaty SN z 16 marca 1999 r., I KZP 4/99, WPP 2002, nr 2; K. Schmidt, Glosa do uchwaty SN z dnia 16 marca 1999 r., I KZP 4/99, OSNKW 1999, nr 5-6, poz. 27, Prok. i Pr. 2001, nr 3; T. Krawczyk, Niektóre konsekwencje teoretyczno-prawne art. 178 kodeksu karnego, Prok. i Pr. 2001, nr 11; R.A. Stefański, Wypadek w komunikacji jako przestęstwo w nowym kodeksie karnym, Prok. i Pr. 1998, nr 10; A. Dziergawka, Ucieczka z miejsca wypadku drogowego, Prok. i Pr. 2008, nr 10.

2 Na przykład uchwalenie wytycznych Sądu Najwyższego z 1975 roku, V KZP 2/74, OSNKW 1975, nr 3-4, poz. 33, czy też wydanie wyroku SN z dnia 12 kwietnia 1995 roku, I KZP 2/95, OSNKW 1995, nr 5-6, poz. 28.

${ }^{3}$ Chodzi zwłaszcza o nowelizację kodeksu karnego z roku 1969 z 12 lipca 1995 (Dz.U. z 1995 r. Nr 95, poz. 475), która wprowadziła do ustawy karnej nowy typ kwalifikowany wypadku w komunikacji, gdy sprawca zbiegł z miejsca zdarzenia (art. 145 $\S 4$ ), czy też zmiany, jakie nastąpiły w ujęciu i traktowaniu takiego zachowania wraz z wejściem w życie kodeksu karnego z 1997 roku (art. 178 § 1 k.k.).

4 Tak m.in. J. Wojciechowski, Kodeks karny. Komentarz. Orzecznictwo, Warszawa 1998, s. 343-344; M. Dąbrowska-Kardas, P. Kardas, Odpowiedzialność za spowodowanie wypadku komunikacyjnego w świetle regulacji k.k. z 1997 r., cz. 2, „Palestra” 1999, nr 3-4, s. 36 n. i s. 41; R.A. Stefański, Przestepstwa przeciwko bezpieczeństwu powszech- 
nie prawnym reguła progresji karania wynikająca z art. $178 \S 1$ k.k. w razie ucieczki sprawcy z miejsca zdarzenia przewiduje wymiar kary od dolnej granicy ustawowego zagrożenia zwiększonej o połowę - w przypadku zbiegnięcia z miejsca ciężkiego wypadku w rozumieniu art. 177 § 2 k.k. nie mniej jednak niż 2 lata $^{5}$ — do górnej jego granicy zwiększonej o połowę. Należy przy tym zwrócić uwagę, iż pomimo zmiany formuły normatywnej znanej z art. 145 § 4 k.k. z 1969 roku wciąż nie brakuje w piśmiennictwie karnistycznym głosów, że zbiegnięcie może być postrzegane także odmiennie, a mianowicie jako ustawowe znamię typu czynu zabronionego, ściślej zaś złożonego typu kwalifikowanego w stosunku do przestępstw stypizowanych w art. 173, 174 oraz art. 177 k.k. ${ }^{6}$

Omawiana okoliczność wywołuje liczne kontrowersje w nauce prawa, w tym wątpliwości o generalnym i — rzec można — „zasadniczym” charakterze, wiążące się z konstytucyjnym aspektem jej wartościowania w ustawie karnej. W tym kontekście rodzi się pytanie - wielokrotnie formułowane już w literaturze ${ }^{7}$ — czy w ogóle, a jeśli tak, to w jakim

neти $i$ w komunikacji, Warszawa 2000, s. 347; J. Raglewski, Model nadzwyczajnego złagodzenia kary w polskim systemie prawa karnego (analiza dogmatyczna w ujęciu materialnoprawnym), Kraków 2008, s. 69; A. Marek, Prawo karne, Warszawa 2011, s. 471; L. Gardocki, Prawo karne, Warszawa 2015, s. 259; T. Krawczyk, Niektóre konsekwencje teoretyczno-prawne art. 178 kodeksu karnego, Prok. i Pr. 2001, nr 11, s. 39; A. Zoll, Glosa do uchwaty SN..., s. 561; W. Wróbel, [w:] Kodeks karny. Część ogólna. Komentarz, red. A. Zoll, t. 1, Warszawa 2007, s. 721, 723; J. Majewski, [w:] Kodeks karny. Część ogólna. Komentarz..., s. 553, 1228; T. Razowski, [w:] Kodeks karny. Część szczególna. Komentarz, red. J. Giezek, Warszawa 2014, s. 363.

${ }^{5}$ Podniesienie minimalnej dolnej granicy odpowiedzialności karnej wobec sprawcy wypadku kwalifikowanego - przez wystąpienie skutku w postaci ciężkiego uszczerbku na zdrowiu lub śmierci pokrzywdzonego - do 2 lat pozbawienia wolności nastąpiło wraz z wejściem w życie ustawy z dnia 23 marca 2017 roku o zmianie ustawy — Kodeks karny oraz niektórych innych ustaw (Dz.U. z 2017 r. poz. 966).

${ }^{6}$ Tak np. M. Budyn-Kulik, Kodeks karny. Komentarz praktyczny, Warszawa 2007, s. 347; R. Citowicz, [w:] M. Królikowski, R. Zawłocki, Kodeks karny. Część szczególna, t. 1. Komentarz art. 117-221, Warszawa 2013, s. 417; K. Schmidt, op. cit., s. 117-118; por. też G. Bogdan, [w:] Kodeks karny. Część szczególna, red. A. Zoll, t. 2, Warszawa 2006, s. 481.

${ }^{7}$ Por. K. Buchała, Niektóre problemy wykładni znamion przestępstw przeciwko bezpieczeństwu w komunikacji, Prok. i Pr. 1998, nr 11-12, s. 17; A. Zoll, Kilka uwag w zwiazku z charakterem prawnym norm..., s. 640. Szerzej na temat zasady nemo tenetur zob. Z. Sobolewski, Samooskarżenie w świetle prawa karnego (nemo se ipsum accusare tenetur), Warszawa 1982, s. 30 n. 
zakresie, ucieczka sprawcy uprzednio popełnionego czynu zabronionego może podlegać prawnokarnej ocenie, ściślej zaś - czy samowolne oddalenie się sprawcy z miejsca popełnionego czynu zabronionego w ogóle może być podstawą dodatkowego, surowszego karania w stosunku do odpowiedzialności, jaka grozi za ten czyn. Ustalenia wymaga więc, czy regulacja ta pozostaje $\mathrm{w}$ zgodzie z zasadą nemo se ipsum accusare tenetur i czy z tej perspektywy zgodna jest z rozwiązaniami konstytucyjnymi.

Przepis art. $178 \S 1$ k.k. będący w zakresie szczególnych zasad wymiaru kary rozwinięciem unormowań ustawy z dnia 20 czerwca 1997 roku Prawo o ruchu drogowym, przewidującym obowiązek pozostania na miejscu przestępstwa komunikacyjnego (art. 44 ust. 2 pkt 3), pośrednio rodzi bowiem normatywną powinność sprawcy dostarczenia danych pozwalających na pociągnięcie go do odpowiedzialności karnej, a więc autodenuncjacji ${ }^{8}$. Łączona $\mathrm{z}$ realizacją prawa do obrony zasada nemo tenetur w Konstytucji RP z 1997 roku wyprowadzana jest z art. 42 ust. 2, który stanowi, iż „każdy, przeciw komu prowadzone jest postępowanie karne, ma prawo do obrony we wszystkich stadiach postępowania”. Może być również wyinterpretowana z zasady domniemania niewinności uregulowanej w art. 42 ust. 3, a także — już na ogólniejszym poziomie - z art. 2 Konstytucji RP określającego fundamentalną zasadę demokratycznego państwa prawnego. Zasada ta wynika też $\mathrm{z}$ wielu aktów prawa międzynarodowego 9 .

Nie bez racji zwraca się w literaturze uwagę, jak czynią to między innymi Kazimierz Buchała i Andrzej Zoll, że regulacja art. 178 § 1 k.k. w zakresie, w jakim przewiduje surowszą odpowiedzialność za zbiegnięcie z miejsca zdarzenia, narusza zasadę domniemania niewinności - surowsze konsekwencje prawne wynikają wszakże z przyjętego w tym przepisie domniemania winy — oraz prawo sprawcy czynu zabronionego do obrony wynikające $\mathrm{z}$ zasady nemo tenetur ${ }^{10}$. Stanowisko to zakłada, iż prawo nie tylko nie może kreować wobec sprawcy

8 Por. A. Zoll, Kilka uwag w związu z charakterem prawnym norm..., s. 640.

${ }^{9} \mathrm{~W}$ tym z Międzynarodowego paktu praw obywatelskich i politycznych ratyfikowanego przez Polskę w 1977 roku (art. 14 ust. 3 lit g.) oraz Europejskiej konwencji o ochronie praw człowieka i podstawowych wolności (art. 6 ust. 1-2).

10 Por. K. Buchała, Niektóre problemy wykładni znamion przestęstw..., s. 17; A. Zoll, Kilka uwag w zwiąku z charakterem prawnym norm..., s. 641. 
nakazu ułatwiania organom procesowym prowadzenia postępowania, w tym powinności wyjaśniania na swoją szkodę lub dostarczania innych dowodów o analogicznym walorze procesowym, lecz także nie może zakazać sprawcy czynu zabronionego utrudniania lub udaremniania organom tego postępowania (na przykład przez zacieranie śladów) - choć może starać się temu zapobiegać, stosując środki przewidziane w przepisach proceduralnych (na przykład tymczasowe aresztowanie). Postawa sprawcy utrudniającego postępowanie karne jest bowiem wyrazem instynktownej reakcji samozachowawczej, a więc z tej perspektywy jest do pewnego stopnia usprawiedliwiona, i jako taka nie tylko nie powinna być w sposób nadzwyczajny karana, lecz — wobec braku normy nakazującej sprawcy czynu zabronionego współpracę z organami procesowymi i powinność samodenuncjacji — w ogóle, w sposób autonomiczny, nie powinna być karana. Wola podjęcia współpracy z organami procesowymi, w warunkach uprawnienia do jej niepodejmowania, może być zatem traktowana jako okoliczność łagodząca, natomiast niewyrażenie tej woli, $\mathrm{w}$ tym ujawniające się $\mathrm{w}$ utrudnianiu organom procesowym wyjaśnienia sprawy, może być oceniane, w kontekście postawy sprawcy, jedynie jako czynnik charakteryzujący jego osobowość i jako taki wpływać na wymiar kary za popełnione przestępstwo. Należy jednakże podkreślić, że zasada nemo tenetur ma ograniczony zakres stosowania. Nie może być więc usprawiedliwieniem każdego zachowania sprawcy uprzednio popełnionego czynu. Nie może w szczególności usprawiedliwiać popełnienia przez sprawcę kolejnego przestępstwa dla uchylenia się od odpowiedzialności za inne przestępstwo ${ }^{11}$. W kwestii zakresu, a i samej zasadności odniesień do zasady nemo tenetur w kontekście surowszej odpowiedzialności za zbiegnięcie z miejsca zdarzenia w komunikacji, w piśmiennictwie karnistycznym przeważa jednak stanowisko bardziej umiarkowane, podkreślające pragmatyzm przyjętego w art. $178 \S 1$ k.k.

11 O takim stanowisku ustawodawcy może świadczyć chociażby typizacja zabójstwa kwalifikowanego z art. $148 \S 2$ k.k., gdy pozostaje ono w związku z innym przestępstwem. Chodzi o takie przypadki, w których zabójstwo - świadka lub ofiary innego przestępstwa - było motywowane wolą uniknięcia odpowiedzialności i służyło ,zacieraniu śladów". 
rozwiązania oraz jego walory sprawiedliwościowe, głębokie uzasadnienie kryminalnopolityczne, a zwłaszcza generalnoprewencyjne ${ }^{12}$.

W kodeksie karnym z 1932 roku zbiegnięcie z miejsca zdarzenia nie było traktowane jako samoistne zachowanie stanowiące autonomiczną podstawę prawnokarnego wartościowania. Nie stanowiło ono ani okoliczności kształtującej podstawę skazania, ani przesłanki modyfikacji granic odpowiedzialności karnej na etapie wymiaru kary. Mogło być natomiast oceniane przez pryzmat art. 247 k.k. typizującego nieudzielenie pomocy, jeśli jednocześnie znamiona tego przestępstwa zostały wyczerpane $^{13}$. Jeżeli więc $\mathrm{w}$ razie ucieczki sprawca nie naruszał prawnego obowiązku niesienia pomocy, jego zachowanie pozostawało prawnokarnie irrelewantne. Sytuacja taka będzie miała miejsce choćby wtedy, gdy powinność udzielenia pomocy w ogóle się nie zaktualizowała bądź stała się bezprzedmiotowa - czy to z tego powodu, iż nie było pokrzywdzonych wymagających takiej pomocy, czy też dlatego, że pomocy udzielił kto inny, czy wreszcie w sytuacji, gdy skutkiem zdarzenia była śmierć jedynego pokrzywdzonego.

Problem ewentualnego stosowania art. 247 k.k. z 1932 roku w wypadku zbiegnięcia wiążącego się z nieudzieleniem pomocy miał też swoje głębsze konteksty pozostające w związku ze specyficzną konstrukcją jego ustawowych znamion. Przepis ten przewidywał bowiem nieodpowiedzialność karną za nieudzielenie pomocy, gdyby prowadziła ona do „narażenia siebie lub osób bliskich na niebezpieczeństwo osobiste”. Wobec tak szerokiej konstrukcji okoliczności wyłączającej karalność za nieudzielenie pomocy część doktryny — nie był to bowiem jedyny kierunek wykładniczy ${ }^{14}$ — interpretując przesłankę „,niebezpieczeństwa

12 Tak m.in. R.A. Stefański, Przestęstwa... s. 380; idem, Ucieczka sprawcy..., s. 11; A. Dziergawka, op. cit., s. 143.

13 Zbiegnięcie z miejsca zdarzenia mogło podlegać ocenie na podstawie § 66 rozporządzenia o ruchu pojazdów mechanicznych na drogach publicznych z 1937 roku, a następnie art. 11 ust. 2 pkt 1 lit. c ustawy z dnia 27 listopada 1961 roku o bezpieczeństwie i porządku ruchu na drogach publicznych, które przewidywały karalność takiego zachowania jako wykroczenia (Dz.U. Nr 53, poz. 295).

${ }^{14}$ Odmiennie w tym zakresie w szczególności orzecznictwo Sądu Najwyższego, który niemal jednomyślnie przyjmował, iż obawa przed odpowiedzialnością karną nie jest okolicznością usprawiedliwiającą w rozumieniu art. 247 k.k. z 1932 roku. Nie jest bowiem niebezpieczeństwem osobistym, a prawnym. Por. wyrok SN z dnia 11 kwietnia 
osobistego", przyjmowała, iż pod tak określony zakres ryzyka należy podciągać także groźbę postępowania karnego i odpowiedzialności karnej za przestępstwo, która jest przecież odpowiedzialnością osobistą, a w związku z tym, że groźba taka jest niewątpliwą dolegliwością, zasadnie można sytuować ją w szeregu „niebezpieczeństw osobistych" ${ }^{15}$. Tym samym zbiegnięcie i nieudzielenie pomocy mające gwarantować nieujawnienie sprawstwa za wypadek odbywałoby się w warunkach wyłączających z tego powodu odpowiedzialność karną za zaniechanie ratowania ofiary wypadku ${ }^{16}$. Na tle takiej wykładni znamion art. 247 k.k. został ugruntowany pogląd, iż za nieudzielenie pomocy odpowiada ten tylko, kto nie wytworzył stanu bezpośredniego niebezpieczeństwa dla cudzych dóbr, o którym stanowi ten przepis ${ }^{17}$. Tym samym więc ucieczka sprawcy z miejsca zdarzenia - nawet gdy nie udzielał on pomocy pokrzywdzonemu zdarzeniem - jawiła się jako zachowanie prawnokarnie irrelewantne ${ }^{18}$.

1958 roku, IV K 175/58, OSN 33/59; wyrok SN z dnia 28 kwietnia 1949 roku, K 414/49, PiP 11/49, s. 154; por. też W. Wolter, Glosa do wyroku SN z 10 lipca 1957 r., IV K 78/57, PiP 1958, nr 2, s. 362; H. Razjman, Glosa do wyroku SN z 10 lipca 1957 r., IV K 78/57, „Orzecznictwo Sądów Polskich i Komisji Arbitrażowych” (dalej: OSPiKA) 1958, nr 5, poz. 119.

15 Szerzej na ten temat zob. W. Radecki, op. cit., s. 6 n.; por. wyrok SN z dnia 16 grudnia 1957 roku, III KO 25/54, cyt. za: H. Rajzman, op. cit.

16 Por. S. Śliwiński, Odpowiedź na pytanie prawne, PiP 1948, nr 8, s. 149; podobnie H. Rajzman, op. cit..

17 Por. wyrok SN z dnia 10 lipca 1957 roku, IV K 78/57, OSNGP 1958, nr 1, poz. 32; wyrok SN z dnia 15 listopada 1961 roku, I K 881/61, OSNGP 1962, nr 1-6, poz. 9; wyrok SN z dnia 31 sierpnia 1962 roku, II K 424/62, RPEiS 1963, nr 2, s. 360. Taka interpretacja przyjmowana była zresztą także pod rządami kodeksu karnego z 1969 roku. Por. np. wyrok SN z dnia 26 września 1972 roku, V KRN 379/72, OSNKW 1973, nr 1, poz. 9.

18 Zmiana postrzegania zaniechania udzielenia pomocy przez sprawcę czynu zabronionego nastąpiła dopiero wraz z modyfikacją konstrukcji ustawowych znamion przestępstwa nieudzielenia pomocy w art. 164 k.k. z 1969 roku. Odmienne ujęcie okoliczności uwalniających od odpowiedzialności za nieudzielenie pomocy zdezaktualizowało dotychczasową wiodącą linię interpretacyjną. Zmiana ryzyka „narażenia siebie lub osób bliskich na niebezpieczeństwo osobiste” na „niebezpieczeństwo utraty życia lub poważnego uszczerbku na zdrowiu" nie pozostawiała w nowym stanie prawnym wątpliwości, iż zbiegnięcie z miejsca zdarzenia i nieudzielenie pomocy nie może być traktowane jako okoliczność gwarantująca sprawcy nieodpowiedzialność za nieudzielenie pomocy z oba- 
W literaturze tego okresu zwracano uwagę na deficyt unormowań w omawianym zakresie. Formułowany był jednocześnie postulat autonomicznej regulacji ucieczki kierowcy z miejsca wypadku, niezależnie od skutków, do jakich ona doprowadziła lub mogła doprowadzić, a więc niezależnie od tego, czy wiązała się z nieudzieleniem pomocy, czy nie. Zdaniem Tadeusza Cypriana w pełni zasadne było traktowanie sekwencyjnie następujących po sobie zachowań sprawcy - spowodowania wypadku oraz ucieczki - jako dwóch czynów, odrębnie ocenianych w warunkach realnego zbiegu przestępstw ${ }^{19}$. Jak argumentował, typizacja przestępstwa zbiegnięcia kierowcy byłaby zasadna nie tylko z perspektywy ogólnie rozumianej konieczności poszukiwania rozwiązań prawnych wzmacniających bezpieczeństwo ruchu drogowego, lecz zwłaszcza ze względu na ciężar gatunkowy i potrzebę zwalczania takich zachowań, które T. Cyprian oceniał jako głęboko „odrażające i aspołeczne”, a przez to wymagające surowej prawnokarnej reakcji ${ }^{20}$.

Także kodeks karny z 1969 roku w pierwotnym brzmieniu nie typizował zbiegnięcia z miejsca zdarzenia jako odrębnego zachowania. Była to jednak okoliczność, zarówno na gruncie doktryny, jak i orzecznictwa

wy o odpowiedzialność karną jako rodzaj „ryzyka osobistego”. Por. A. Bachrach, Przestepstwa $i$ wykroczenia drogowe w prawie polskim, Warszawa 1980, s. 384.

19 T. Cyprian, op. cit., s. 89. Brak w zakresie prawnokarnej regulacji zbiegnięcia sprawcy zdarzenia w komunikacji autor tłumaczył relatywnie niskim stanem rozwoju motoryzacji w okresie pracy nad obowiązującym prawem na ziemiach polskich. Zwracał jednocześnie uwagę, iż w państwach, w których motoryzacja rozwijała się znacznie dynamiczniej (takich jak na przykład Francja, Włochy, Szwajcaria, Wielka Brytania czy Niemcy), zbiegnięcie z miejsca wypadku stanowiło przedmiot autonomicznej regulacji kodeksowej od dawna; zob. ibidem, s. 91-94.

${ }^{20}$ Ibidem, s. 95. Warto zwrócić uwagę, że postulat ten został uwzględniony w trakcie prac Komisji Kodyfikacyjnej opracowującej projekt nowego kodeksu karnego z 1961 roku. Proponowany w tym zakresie przepis art. 238 brzmiał: „Kierowca pojazdu, który po spowodowaniu katastrofy lub wypadku, o których mowa w art. 230, 232 lub 233, w celu uchylenia się od odpowiedzialności karnej albo utrudnienia właściwym organom ustalenia przebiegu katastrofy lub wypadku opuszcza miejsce, w którym one nastąpiły, podlega karze pozbawienia wolności do lat 2". Z $\S 2$ tego przepisu, regulującego zbiegnięcie kwalifikowane, wynikało natomiast, że „Jeżeli sprawca opuszcza miejsce katastrofy lub wypadku, w którym nastąpiła śmierć człowieka, albo przed udzieleniem niezbędnej pomocy osobie, która doznała uszkodzenia ciała lub rozstroju zdrowia, podlega karze pozbawienia wolności do lat 5"; zob. ibidem, s. 94. Kryminalizację zbiegnięcia z miejsca zdarzenia przewidywał także projekt kodeksu z 1963 roku (art. 254).

Nowa Kodyfikacja Prawa Karnego 53, 2019

(C) for this edition by CNS 
postrzegana jako szczególnie naganna ${ }^{21}$. Jej ocena często była łączona, czy wręcz identyfikowana, z uchylaniem się sprawcy od udzielenia pomocy pokrzywdzonemu zdarzeniem, a dylemat rodzący spór o to, czy spowodowanie wypadku, po którym nastąpiła ucieczka połączona z nieudzieleniem pomocy, traktować jako jeden czyn, czy jako ich zbieg, a jeśli tak, to realny czy pozorny, był jednym z wiodących, wyraźnie zaznaczających swą obecność, dylematów prawa karnego, przez wiele lat dzielących doktrynę i judykaturę.

Ucieczka postrzegana przez pryzmat naruszenia obowiązku niesienia pomocy traktowana była w tym czasie jako jaskrawe pogwałcenie elementarnej powinności każdego kierowcy — zwłaszcza kierowcy będącego sprawcą zdarzenia - i jako taka wpływająca obciążająco na wymiar kary. Obciążający charakter zbiegnięcia z miejsca wypadku podkreśliły wprost wytyczne Sądu Najwyższego z 28 lutego 1975 roku. Zgodnie z tezą 36

Nieudzielenie pomocy ofierze wypadku przez sprawcę przestępstwa drogowego, mimo że jest to możliwe, stanowi istotną okoliczność obciążającą, podobnie jak i ucieczka sprawcy takiego przestępstwa z miejsca wypadku² 22

Okoliczności te, negatywnie charakteryzujące sposób zachowania się sprawcy po popełnieniu przestępstwa, zostały wyraźnie w wytycznych oddzielone i traktowane jako w pełni autonomiczne okoliczności obciążające. Ich łączne wystąpienie sumarycznie wzmacniało więc obostrzający wpływ na wymiar kary. W takim wypadku w zachowaniu sprawcy kumulowała się naganność wynikająca równocześnie z działania (zbiegnięcia) oraz zaniechania (nieudzielenia pomocy) sprawcy. W doktrynie pod rządami kodeksu karnego z 1969 roku nie było zgody nie tylko co do samej kwestii potrzeby i możliwości ustawowego uregulowania zbiegnięcia z miejsca zdarzenia, lecz także formy, w jakiej ewentualnie miałoby to nastąpić. $\mathrm{Z}$ jednej strony, zwolennicy takiej regulacji de lege ferenda proponowali alternatywnie bądź to autonomiczną kryminalizację zbiegnięcia z miejsca zdarzenia przez dodanie do art. 145 k.k. kolejnego, czwartego paragrafu,

21 Por. uchwała SN z dnia 28 lutego 1975 roku, V KZP 2/74, OSNKW 1075, nr 3-4, poz. 33; wyrok SN z dnia 2 lipca 1980 roku, V KRN 127/80, OSNPG 1981, nr 5, poz. 47; K. Pawelec, op. cit., s. 221 n.

${ }^{22}$ Uchwała SN z dnia 28 lutego 1975 roku, V KZP 2/74, OSNKW 1975, nr 3-4, poz. 33 .

Nowa Kodyfikacja Prawa Karnego 53, 2019

(C) for this edition by CNS 
który tworzyłby typ kwalifikowany wypadku ${ }^{23}$, bądź to rozszerzenie surowszej odpowiedzialności przewidzianej w art. $145 \S 3$ k.k. o takie właśnie zachowanie po popełnieniu przestępstwa ${ }^{24}$. Wskazywana była także możliwość stworzenia odrębnego przestępstwa zbiegnięcia z miejsca przestępstwa drogowego ${ }^{25}$. Z drugiej strony, propozycja kryminalizacji ucieczki z miejsca wypadku spotkała się w literaturze z krytyką, uzasadnianą względami zarówno kryminologicznymi, jak i teoretycznoprawnymi. Podnoszono zwłaszcza, że nie ma jakiegokolwiek uzasadnienia dla odrębnego kryminalizowania zbiegnięcia z miejsca wypadku, skoro sprawca nie ma prawnego obowiązku pozostania na miejscu innych nieumyślnych przestępstw przeciwko życiu i zdrowiu, czy też przestępstw w ogóle. Ponadto taka regulacja byłaby w istocie „kryminalizacją zastępczą” przeznaczoną dla przypadków, w których nie można określić psychomotorycznego stanu „sprawcy-zbiega”, a przy okazji regulacją „odciągającą policję od ważniejszych zadań" ${ }^{26}$. Ostatecznie jednak nowelizacja kodeksu karnego z 12 lipca 1995 roku dodała do art. 145 k.k. kolejny paragraf, w którym okoliczność ta została potraktowana jako ustawowe znamię typu czynu zabronionego, ściślej zaś typu kwalifikowanego wypadku w komunikacji. Zarówno usytuowanie, jak i konstrukcja dodanego przepisu nie pozostawiały wątpliwości, iż ustawodawca tworzy nie tylko nową normę sankcjonującą, lecz także sankcjonowaną. Artykuł 145 § 4 k.k. brzmiał: ,Sprawca czynu określonego w $\S 1$ lub 2, który zbiegł z miejsca zdarzenia, podlega karze pozbawienia wolności od 1 roku do 10 lat". Sankcja przewidziana za zbiegnięcie sprawcy była zatem identyczna jak w przypadku spowodowania wypadku w stanie nietrzeźwości (art. 145 § 3 k.k.). Przestępstwo kwalifikowane $\mathrm{z}$ art. $145 \S 4$ było przestępstwem nieumyślnym, mimo iż zbiegnięcie miało niewątpliwie charakter umyślny, a wręcz celowy ${ }^{27}$.

23 Tak np. J. Wojciechowski, Bezkarność uciekiniera, „Rzeczpospolita” 1992, nr 255.

24 Por. R.A. Stefański, Glosa do wyroku SN..., s. 121-122; idem, Ucieczka spraw$c y \ldots$, s. 10 .

25 Tak K.J. Pawelec, op. cit., s. 210 n.

26 Por. K. Buchała, Problemy kryminalizacji..., s. 14-15, 25; idem, Zbiegnięcie kierującego pojazdem mechanicznym z miejsca zdarzenia, [w:] Rozważania o prawie karnym. Księga pamiątkowa z okazji siedemdziesięciolecia urodzin Profesora Aleksandra Ratajczaka, red. A.J. Szwarc, Poznań 1999, s. 8-9.

27 Por. R.A. Stefański, Ucieczka sprawcy..., s. 23. 
Kryminalizacja zbiegnięcia z miejsca zdarzenia w kodeksie karnym z 1969 roku, jak można się było spodziewać, obserwując polaryzację poglądów przed przyjęciem nowelizacji z 12 lipca 1995 roku, spotkała się z mieszanym przyjęciem. Część przedstawicieli nauki prawa poddała ją surowej krytyce, dostrzegając tym rozwiązaniu cechy ustawowego nakazu autodenuncjacji wbrew zasadzie nemo tenetur. Regulacji tej jednocześnie zarzucano, iż przewiduje sankcję na podstawie fałszywej sugestii, że z miejsca zdarzenia uciekają wyłącznie sprawcy znajdujący się w stanie nietrzeźwości, co falsyfikuje rzeczywistość i motywację takich postaw $^{28}$. W literaturze zwrócono także uwagę, iż przyjęta zmiana jest nie tylko rozwiązaniem kryminologicznie nieuprawnionym, lecz także fragmentarycznym. Brakowało w nim bowiem systemowego podejścia ustawodawcy do regulowanej kwestii. Krytycy tego rozwiązania podnosili, iż formuła i lokalizacja dodanego przepisu wyraźne wiąże jego normę $\mathrm{z}$ art. $145 \S 1-2$, pozwalając na posługiwanie się nim wyłącznie $\mathrm{w}$ odniesieniu do sprawcy wypadku w komunikacji. Tymczasem problem, jaki dodany przepis miałby rozwiązać, ma znacznie szerszy zakres - mianowicie aktualizuje się on również w wypadku innych, w tym groźniejszych, przestępstw przeciwko bezpieczeństwu w komunikacji, stypizowanych w art. 136 k.k. i art. 137 k.k., a także w części wojskowej $\mathrm{w}$ art. 323 k.k., które mogą zostać popełnione w analogicznie nagannych okolicznościach ${ }^{29}$. Różnice między wypadkiem a katastrofą mają bowiem charakter głównie ilościowy, a nie jakościowy. Ciężar katastrofy tym bardziej więc uzasadnia surowszą odpowiedzialność w razie zbiegnięcia z jej miejsca. O ile zatem sprawca „,mniejszego zdarzenia komunikacyjnego", który zbiegł z jego miejsca, ponosił odpowiedzialność za typ kwalifikowany, o tyle zbiegnięcie z miejsca ,większego zdarzenia komunikacyjnego", jakim jest katastrofa, nie wiązało się z obostrzeniem odpowiedzialności in abstracto w ramach kwalifikowanego typu, choć niewykluczona była surowsza odpowiedzialność in concreto $\mathrm{w}$ ramach zwyczajnego wymiaru kary. Jednego z nich obowiązywał więc zakaz oddalania się z miejsca zdarzenia, którego naruszenie skutkowało surowszą kwalifikacją, podczas gdy wobec drugiego ustawa takiego obowiązku nie

28 Por. K. Buchała, Problemy kryminalizacji..., s. 12 n.; idem, Ucieczka kierowcy..., s. 37; A. Marek, op. cit., s. 420.

${ }^{29}$ Por. M. Dąbrowska-Kardas, P. Kardas, Kryminalizacja ucieczki..., cz. 1, s. 13 n. 
formułowała. Relacja wyłączania, w jakiej pozostają te unormowania, nie pozwalała też na posłużenie się konstrukcją kumulatywnego zbiegu przepisów ustawy właściwego regule krzyżowania się ich zakresów. W sytuacji więc, gdy z miejsca katastrofy lub miejsca jej niebezpieczeństwa zbiegł jej sprawca albo żołnierz z miejsca wypadku pojazdu wojskowego, pod rządami kodeksu karnego z 1969 roku na płaszczyźnie ustawowego wymiaru kary nie ponosił żadnych dodatkowych konsekwencji. Było to zatem rozwiązanie nie tylko niekompletne, lecz także całkowicie niespójne.

Formułowane na gruncie tej krytyki postulaty ostatecznie zostały uwzględnione w kodeksie karnym z 1997 roku, który zbiegnięcie sprawcy potraktował w sposób ,generalny”, jako jedną z podstaw nadzwyczajnego obostrzenia kary wobec sprawcy nie tylko wypadku w komunikacji (art. 177 k.k.), ale też spowodowania katastrofy (art. 173 k.k.) oraz sprowadzenia jej niebezpieczeństwa (art. 174 k.k.), a poprzez regulację art. $355 \S 3$ k.k. także żołnierza powodującego wypadek w komunikacji $\mathrm{w}$ rozumieniu art. $355 \S 1-2$ k.k. Strona przedmiotowa zbiegnięcia, o którym stanowi art. $178 \S 1$ k.k., nie wywołuje poważniejszych wątpliwości wykładniczych. Takie zachowanie jest powszechnie traktowane jako synonim „ucieczki”, a więc oddalenie się z jakiegoś miejsca, opuszczenie go, wbrew istniejącemu obowiązkowi pozostania w nim ${ }^{30}$. Zbiec można więc tylko w formie działania. Pojęciowo niemożliwe jest zaś zbiegnięcie ,zaniechane”. Znacznie więcej kłopotów interpretacyjnych towarzyszy dookreśleniu treści strony podmiotowej. Przeważa pogląd, iż zbiegnięcie musi mieć charakter kierunkowy, musi być więc jednoznacznie zabarwione intencjonalnie. „Nastawienie psychiczne” sprawcy musi obejmować uniknięcie odpowiedzialności karnej albo co najmniej uniknięcie surowszej odpowiedzialności karnej, czemu ma służyć uniemożliwienie jego identyfikacji, względnie jego stanu bądź też okoliczności, w jakich doszło do popełnienia czynu ${ }^{31}$. W tym znaczeniu — choć przepis wprost celu zachowania sprawcy nie wskazuje — ze względu na motywację, która przyświeca podjęciu decyzji i jej realizacji, zbie-

30 Por. Słownik języka polskiego, red. W. Doroszewski, t. 9, Warszawa 1967, s. 445; oraz Słownik języka polskiego, red. W. Doroszewski, t. 10, Warszawa 1968, s. 911; Słownik języka polskiego, red. M. Szymczak, t. 3, Warszawa 1989, s. 982.

31 J. Wojciechowski, Kodeks karny. Komentarz. Orzecznictwo, Warszawa 1998, s. 317. 
gnięcie ma charakter nie tylko umyślny, lecz wręcz kierunkowy, choć może wynikać z zachowania nieumyślnego ${ }^{32}$. Jak wprost stwierdził Sąd Najwyższy:

Zbiegnięcie $\mathrm{z}$ miejsca zdarzenia [...] ma miejsce wówczas, gdy sprawca oddala się z miejsca wypadku w zamiarze uniknięcia odpowiedzialności karnej, w szczególności uniemożliwienia lub utrudnienia ustalenia jego tożsamości, okoliczności zdarzenia i stanu nietrzeźwości — na tle art. 178 k.k. także pozostawania pod wpływem środka odurzającego ${ }^{33}$.

Wystarczające jest zatem motywowanie oddalenia się z miejsca wypadku choć jednym z tych celów. Tym samym motywacja takiego zachowania jakimkolwiek innym celem (na przykład wezwaniem pomocy, uniknięciem samosądu, ratowaniem własnego życia lub zdrowia) nie odpowiada treścią strony podmiotowej istocie zbiegnięcia. Negatywna ocena sprawcy, prowadząca do surowszej odpowiedzialności karnej, wchodzi bowiem w grę jedynie wówczas, gdy jego zbiegnięcie z miejsca zdarzenia stanowi jednocześnie ,ucieczkę przed odpowiedzialnością”, zresztą nie tylko karną, ale i cywilną.

W kontekście treści strony podmiotowej towarzyszącej zbiegnięciu w nauce prawa karnego zaznaczył się wyraźny nurt interpretacyjny przyjmujący, iż wyłącza je tak zwany powypadkowy szok psychiczny. Stan taki zakłóca bowiem po stronie sprawcy możliwość zarówno oceny własnego zachowania, jak i pokierowania nim ${ }^{34}$. Pogląd ten jest trudny do zaakceptowania zwłaszcza z perspektywy powszechnie akcentowanej kryminalnopolitycznej funkcji tej regulacji i jej generalnoprewencyjnego charakteru. Przy takim kierunku interpretacji każdy sprawca-uciekinier post factum mógłby się bowiem powoływać na szok psychiczny, całkowicie zresztą niezależnie od tego, czy rzeczywiście stan taki zaistniał.

32 Por. R.A. Stefański, Ucieczka sprawcy..., s. 21-23; G. Bogdan, op. cit., s. 479; por. wyrok SN z dnia 18 maja 2009 roku, III KK 22/09, KZS 2010, nr 10, poz. 12.

33 Por. wyrok SN z dnia 15 marca 2001 roku, III KKN 492/99, OSNKW 2001, nr 7-8, poz. 52; wyrok SN z dnia 27 marca 2001 roku, IV KKN 175/00, Legalis; wyrok SN z dnia 30 marca 2005 roku, WA 3/05, OSNwSK 2005, nr 1, poz. 639; wyrok SN z dnia 18 maja 2009 roku, III KK 22/09, KZS 2010, nr 10, poz. 12; wyrok SN z dnia 17 stycznia 2012 roku, V KK 389/11, OSNKW 2012, nr 4, poz. 42; wyrok SN z dnia 1 marca 2011 roku, V KK 284/10, OSNKW 2011, nr 5, poz. 45.

34 Tak m.in. J. Wojciechowski, Kodeks karny. Komentarz..., s. 317; N. Kłączyńska, [w:] Kodeks karny. Czesśś ogólna. Komentarz, red. J. Giezek, Warszawa 2007, s. 337. 
Notabene prawdopodobieństwo zaistnienia takiego stanu jest niemałe, choćby ze względu na dynamikę zdarzeń, o których mowa w art. 178 k.k., ich stronę podmiotową oraz charakter skutków. Przyjęcie takiego poglądu prowadziłoby do przesunięcia ciężaru dowodu w zakresie diagnostyki „stanu szoku” na organ procesowy. Innymi słowy, sprawcy należałoby dowieść, iż oddalenie się z miejsca zdarzenia nastąpiło z innego powodu niż „,szok powypadkowy”. W praktyce ryzyko niepowodzenia dowodowego procedowania $\mathrm{w}$ tym kierunku zdaje się aż nadto widoczne. Taka wykładnia stosowania omawianej przesłanki nadzwyczajnego obostrzenia kary prowadziłaby do jej faktycznego zmarginalizowania i zniweczenia kryminalnopolitycznej funkcji, którą w zamyśle ustawodawcy miała realizować. W kontekście poczynionych uwag zasadniejsze wydaje się zatem postrzeganie i ocenianie „szoku pozdarzeniowego" przez pryzmat okoliczności umniejszającej winę — tam, gdzie był on usprawiedliwiony - i jako takiej wpływającej in concreto na wymiar kary nadzwyczajnie obostrzonej, niż traktowanie go jako okoliczność wyłączającą winę, a tym samym regułę nadzwyczajnego wymiaru kary z art. 178 k.k.

W kontekście poruszanej problematyki należy zwrócić uwagę na kwestię rodzaju dobra lub dóbr chronionych omawianą regulacją prawną. Pojawia się mianowicie pytanie, jakie jest ratio legis ustawowego zakazu ucieczki sprawcy z miejsca zdarzenia komunikacyjnego i surowszej odpowiedzialności karnej w razie jego naruszenia. Innymi słowy, co decyduje o zobowiązaniu akurat sprawcy nieumyślnego przestępstwa przeciwko bezpieczeństwu w komunikacji do pozostania na miejscu zdarzenia, skoro takiego obowiązku ustawa nie przewiduje wobec sprawców innych przestępstw nieumyślnych. Dobra takiego omawiany przepis nie wskazuje bowiem wprost, a jedyną wskazówką w tym zakresie może być determinujące rodzajowy przedmiot ochrony usytuowanie art. 178 k.k. w rozdziale przestępstw przeciwko bezpieczeństwu w komunikacji. Już na wstępie należy wykluczyć nasuwającą się prima facie jako oczywista odpowiedź na postawione pytanie, iż w przepisie tym chodzi o zwiększenie ochrony życia i zdrowia człowieka znajdującego się w stanie zagrożenia i zobowiązanie sprawcy do udzielenia mu pomocy. Te bowiem dobra prawne chronione są w sposób autonomiczny odrębną normą prawną wynikającą z art. 162 k.k., a nie można — jak już wspomniano — wykluczyć również sytuacji, w której w ogóle dobra te nie znajdą się w stanie 
zagrożenia, stan ten uchyli kto inny lub w ogóle się on nie zaktualizuje, jak choćby w wypadku, gdy jedynym skutkiem zdarzenia będzie skutek śmiertelny ${ }^{35}$. Omawiany zakaz ucieczki tymczasem obowiązuje niezależnie od potrzeby i możliwości udzielenia pomocy innej osobie.

Teoretycznie może w tym przypadku chodzić o ochronę trzech wartości społecznych. Na plan pierwszy zdaje się wysuwać interes wymiaru sprawiedliwości. Nie budzi przecież wątpliwości, iż ucieczka sprawcy utrudnia, a nawet może uniemożliwić, wyjaśnienie okoliczności zdarzenia i jego przebieg, co w konsekwencji uderza w samą ideę sprawiedliwości ${ }^{36}$. Tezy takiej nie wspiera jednak lokalizacja omawianego przepisu. Dobrami prawnymi, które niewątpliwie doznają uszczerbku w wypadku ucieczki sprawcy, są też dobra osób pokrzywdzonych jednym ze zdarzeń, o których stanowi art. 178 k.k., z wyłączeniem — jak wspomniano ich zdrowia i życia chronionych w sposób autonomiczny normą zawartą w art. 162 k.k. Chodzi więc zwłaszcza o możliwość skutecznego dochodzenia względem sprawcy stosownych roszczeń o naprawienie szkody, względnie uczynienie zadość w związku z doznaną krzywdą, których realizację uniemożliwia lub w znacznym stopniu utrudnia niemożność nie tylko identyfikacji sprawcy, lecz także odtworzenia przebiegu zdarzeń, które do takich następstw doprowadziły. Wreszcie w przepisie tym w grę może wchodzić tak zwana kryminalizacja zastępcza, której zadaniem jest wzmożona ochrona bezpieczeństwa w komunikacji przed sprawcami, których szczególnie naganny tempore criminis stan — nietrzeźwości lub odurzenia - podpowiada intuicja, którego to jednak stanu z powodu zbiegnięcia nie można im dowieść ${ }^{37}$. Z tej perspektywy regulacja ta byłaby więc surogatem surowszej karalności za domniemywany stan zwiększonej naganności, w jakim sprawca mógł się znajdować, w razie niemożliwości jego dowiedzenia. Innymi słowy, punktem wyjścia tej regulacji byłby zatem założony a priori, choć niezweryfikowany dowodowo stan nietrzeźwości lub odurzenia sprawcy-uciekiniera. Tym samym opierałaby

35 Por. K. Buchała, Problemy kryminalizacji..., s. 14 n.

36 Por. T. Cyprian, op. cit., s. 87 n.

37 Por. K. Buchała, Niektóre zagadnienia nowelizacji prawa karnego, PiP 1996, nr 3, s. 10; idem, Zbiegnięcie z miejsca wypadku drogowego, „Przegląd Sądowy” 1996, nr 1, s. 10; szerzej na ten pojęcia kryminalizacji zastępczej zob. L. Gardocki, Uproszczone formy penalizacji, PiP 1975, z. 8-9. 
się ona na wątpliwym kryminologicznie, choć dość powszechnie panującym przekonaniu, iż z miejsca zdarzenia uciekają tylko winni.

Przyjmując ten punkt widzenia, ustawodawca wychodziłby z założenia, że skoro sprawca zbiegł, uniemożliwiając diagnostykę stanu swego organizmu, to powinien ponieść taką samą odpowiedzialność jak w wypad$\mathrm{ku}$, gdy istotnie w takim stanie się znajduje. Problem w tym, że przy takim założeniu wyjściowym kłopot pojawia się nie tylko wówczas, gdy tempore criminis sprawca w rzeczywistości w takim stanie się nie znajduje, lecz także gdy w rzeczywistości w stanie tym się znajdował, choć ujawnia się to na różnych etapach sprawowania wymiaru sprawiedliwości. W pierwszym przypadku dojdzie bowiem do przyjęcia fikcji winy, a w konsekwencji niedopuszczalnego w świetle obowiązujących standardów prawa karnego posłużenia się jej domniemaniem. W drugim natomiast do sytuacji, w której przesłanka zbiegnięcia, która miała być alternatywą wobec wątpliwości co do rzeczywistego stanu sprawcy, uzasadniającą jego surowsze ukaranie, może być w praktyce sądowego wymiaru kary oceniana łącznie (kumulatywnie) z nietrzeźwością lub odurzeniem sprawcy prowadzącego pojazd. Dojdzie więc w takiej sytuacji do zdublowania nagannej oceny tej samej okoliczności wpływającej na wymiar kary — po pierwsze założonej, po drugie rzeczywistej - a w konsekwencji wymierzenia kary ponad stopień „rzeczywistej” winy sprawcy. W tym stanie rzeczy — na tle wyrażonych uwag, a nierzadko pomimo ich wymowy — ratio legis omawianej regulacji należy łączyć zwłaszcza z potrzebą zwiększenia ochrony bezpieczeństwa w komunikacji. Przychylając się do stanowiska zajętego przez K. Buchałę, należy zgodzić się z poglądem, iż u podłoża omawianej regulacji, zdiagnozowanej przez tego autora właśnie jako forma „kryminalizacji zastępczej”, legły względy kryminalnopolityczne i generalnoprewencyjne, mocno zabarwione „dobrymi intencjami” ustawodawcy. Te zaś, jak uczy doświadczenie i wynika z obserwacji, wpisują się w ujawniający się czasami w toku tworzenia prawa — niegdyś sporadycznie, współcześnie coraz częściej — nurt uświęcania kreowanych rozwiązań prawnych celami, których realizacji mają służyć, bez względu na poprawność normatywnej formy, jaka środkom tym została nadana. 


\section{Bibliografia}

Bogdan G., [w:] Kodeks karny. Część szczególna, red. A. Zoll, t. 2, Warszawa 2006.

Buchała K., Niektóre problemy wykładni znamion przestęsstw przeciwko bezpieczeństwu w komunikacji, „Prokuratura i Prawo” 1998, nr 11-12.

Buchała K., Niektóre zagadnienia nowelizacji prawa karnego, „Państwo i Prawo” 1996, nr 3.

Buchała K., Problemy kryminalizacji ucieczki uczestnika karalnego zdarzenia w ruchu drogowym, „Prokuratura i Prawo” 1995, nr 2.

Buchała K., Przestępne zaniechanie udzielenia pomocy $w$ niebezpieczeństwie grożacym życiu człowieka, „Państwo i Prawo” 1960, nr 12.

Buchała K., Zbiegnięcie kierującego pojazdem mechanicznym z miejsca zdarzenia, [w:] Rozważania o prawie karnym. Księga pamiątkowa z okazji siedemdziesięciolecia urodzin Profesora Aleksandra Ratajczaka, red. A.J. Szwarc, Poznań 1999.

Buchała K., Zbiegnięcie z miejsca wypadku drogowego, „Przegląd Sądowy” 1996, nr 1.

Budyn-Kulik M., Kodeks karny. Komentarz praktyczny, Warszawa 2007.

Citowicz R., [w:] M. Królikowski, R. Zawłocki, Kodeks karny. Część szczególna, t. 1. Komentarz art. 117-221, Warszawa 2013.

Cyprian T., Ucieczka kierowcy, „Palestra” 1962, nr 1-2.

Dąbrowska-Kardas M., Kardas P., Kryminalizacja ucieczki sprawcy wypadku drogowego z miejsca zdarzenia $w$ świetle nowelizacji k.k. z 12 lipca 1995 r., cz. 1, „Palestra” 1996, nr 3-4.

Dąbrowska-Kardas M., Kardas P., Kryminalizacja ucieczki sprawcy wypadku drogowego z miejsca zdarzenia $w$ świetle nowelizacji k.k. z 12 lipca 1995 r., cz. 2, „Palestra” 1996, nr 5-6.

Dąbrowska-Kardas M., Kardas P., Odpowiedzialność za spowodowanie wypadku komunikacyjnego $w$ świetle regulacji k.k. z 1997 r., cz. 2, „Palestra” 1999, nr 3-4.

Dziergawka A., Ucieczka z miejsca wypadku drogowego, „Prokuratura i Prawo” 2008, nr 10.

Gardocki L., Prawo karne, Warszawa 2015.

Gardocki L., Uproszczone formy penalizacji, „Państwo i Prawo” 1975, z. 8-9.

Iwaniec J., Glosa do uchwaty SN z 16 marca 1999 r., I KZP 4/99, „Wojskowy Przegląd Prawniczy" 2002, nr 2.

Kłączyńska N., [w:] Kodeks karny. Część ogólna. Komentarz, red. J. Giezek, Warszawa 2007.

Krawczyk T., Niektóre konsekwencje teoretyczno-prawne art. 178 kodeksu karnego, „Prokuratura i Prawo" 2001, nr 11.

Majewski J., [w:] Kodeks karny. Część ogólna. Komentarz, red. A. Zoll, t. 1, Warszawa 2007.

Marek A., Prawo karne, Warszawa 2011.

Paprzycki L.K., Ucieczka z miejsca wypadku drogowego, „Rzeczpospolita” 1995, nr 118.

Pawelec K.J., Ucieczka sprawcy wypadku drogowego w świetle prawa karnego i badań, „Stużba MO” 1986, nr 3-4. 
Radecki W., Odpowiedzialność karna kierowcy za nieudzielenie pomocy ofierze wypad$k u$, „Problemy Praworządności” 1975, nr 10.

Raglewski J., Model nadzwyczajnego złagodzenia kary w polskim systemie prawa karnego (analiza dogmatyczna w ujęciu materialnoprawnym), Kraków 2008.

Rajzman H., Glosa do wyroku SN z 10 lipca 1957 r., IV K 78/57, „Orzecznictwo Sądów Polskich i Komisji Arbitrażowych" 1958, nr 5, poz. 119.

Razowski T., [w:] Kodeks karny. Część szczególna. Komentarz, red. J. Giezek, Warszawa 2014.

Schmidt K., Glosa do uchwaty SN z dnia 16 marca 1999 r., I KZP 4/99, OSNKW 1999, nr 5-6, poz. 27, „Prokuratura i Prawo” 2001, nr 3.

Stownik języka polskiego, red. W. Doroszewski, t. 9-10, Warszawa 1967-1968.

Stownik języka polskiego, red. M. Szymczak, t. 3, Warszawa 1989.

Sobolewski Z., Samooskarżenie w świetle prawa karnego (nemo se ipsum accusare tenetur), Warszawa 1982.

Stefański R.A., Przestęstwa przeciwko bezpieczeństwu powszechnemu $i$ w komunikacji, Warszawa 2000.

Stefański R.A., Ucieczka sprawcy z miejsca wypadku drogowego, „Prokuratura i Prawo” 1996, nr 1.

Stefański R.A., Wypadek w komunikacji jako przestęstwo w nowym kodeksie karnym, „Prokuratura i Prawo” 1998, nr 10.

Śliwiński S., Odpowiedź na pytanie prawne, „Państwo i Prawo” 1948, nr 8.

Wojciechowski J., Bezkarność uciekiniera, „Rzeczpospolita” 1992, nr 255.

Wojciechowski J., Kodeks karny. Komentarz. Orzecznictwo, Warszawa 1998.

Wolter W., Glosa do wyroku SN z 10 lipca 1957 r., IV K 78/57, „Państwo i Prawo” 1958, nr 2.

Wróbel W., [w:] Kodeks karny. Część ogólna. Komentarz, red. A. Zoll, t. 1, Warszawa 2007.

Zoll A., Glosa do uchwaty SN z 16 marca 1999 r., I KZP 4/99, „Orzecznictwo Sądów Polskich" 1999, nr 11.

Zoll A., Kilka uwag w zwiazku z charakterem prawnym norm sankcjonujacych wynikajacych $z$ art. 178 \& 1 k.k., [w:] Teoretyczne i praktyczne problemy wspótczesnego prawa karnego. Ksiegga Jubileuszowa dedykowana Profesorowi Tadeuszowi Bojarskie$m u$, red. A. Michalska-Warias, I. Nowikowski, J. Piórkowska-Flieger, Lublin 2011.

Zoll A., Odpowiedzialność karna kierowcy za spowodowanie wypadku i nieudzielenie pomocy jego ofierze, „Wojskowy Przegląd Prawniczy” 1969, nr 1.

Zoll A., Odpowiedzialność karna kierowcy za ucieczkę, „Nowe Prawo” 1970, nr 10. 


\title{
On criminal-law issues of the assassment of an offender fleeing the scene of an traffic crime
}

\begin{abstract}
Summary
On the grounds of criminal-law research, the article tries to conduct a dispute analysis of the issues of a legal evaluation of "the fleeing" of a road traffic participant from the scene of the communication event. The subject of the analysis is not only the concept of "the escape" - its subjective aspect - but also its perception on the grounds of the past and the presently applicable legal solutions. Attention was drawn to the change in function that these circumstances fulfilled and to how, within years, its influence on justice in cases of communication crimes - from the circumstances restricting the dimension of punishment in the phase of judicial substantiation, via creation of the marks of the qualified type of forbidden act, to a general (cumulative) premise of extraordinary restriction of punishment. One of the leading ideas of this work is the case of the ratio legis regulation of the fleeing of the road traffic participant from the scene of the communication event. In light of the accepted legal solutions it is unclear what determines its object of protection, and so the protection of which legal goods this regulation serves.
\end{abstract}

Keywords: traffic, the safety of communication, escape, coincidence, vehicle. 